\title{
Prescription for Health: Changing Primary Care Practice to Foster Healthy Behaviors
}

\author{
Maribel Cifuentes, RN, BSN ${ }^{1}$ \\ Douglas H. Fernald, $M A^{1}$ \\ Larry A. Green, $M D^{1}$ \\ Linda J. Niebauer ${ }^{1}$ \\ Benjamin F. Crabtree, $P b D^{2}$ \\ Kurt C. Stange, $M D, P b D^{3}$ \\ Susan B. Hassmiller, PbD, RN ${ }^{4}$ \\ 'Prescription for Health National Program \\ Office, Department of Family Medicine, \\ University of Colorado Health Sciences \\ Center, Aurora, Colo
}

${ }^{2}$ Department of Family Medicine, University of Medicine and Dentistry, Robert Wood

Johnson Medical School, Somerset, NJ

${ }^{3}$ Department of Family Medicine, Case Western Reserve School of Medicine, Cleveland, Ohio

${ }^{4}$ The Robert Wood Johnson Foundation, Princeton, NJ

Conflicts of interest: none reported

\section{CORRESPONDING AUTHOR}

Maribel Cifuentes, RN, BSN

Prescription for Health National Program

Office

PO Box 6508, Mail Stop F-496

Aurora, CO 80045-0508

Maribel.Cifuentes@uchsc.edu

\begin{abstract}
PURPOSE The leading causes of premature death in the United States are linked to 4 behaviors: smoking, unhealthy diet, physical inactivity, and risky alcohol use. We report lessons from 17 exploratory projects funded under Prescription for Health that tested the feasibility of innovative behavior change strategies for at least 2 of these behaviors in primary care practices.
\end{abstract}

METHODS Seventeen practice-based research networks (PBRNs) implemented and evaluated tools, cues, and techniques in 120 family medicine, internal medicine, pediatric, and nursing practices across an ethnically diverse sample of adults, children, and adolescents in rural and urban settings. We reviewed progress reports and notes from site visits and 3 meetings to generate overarching lessons.

RESULTS PBRNs successfully implemented their projects in diverse practices despite reported logistical challenges and practice constraints. The networks showed that distributing the effort across the care team and throughout the practice and community is possible. Although each behavior required specific attention, each did not require its own separate staff and system. Three models emerged as helpful guides for the comprehensive redesign of health behavior counseling, but they require adaptation for use in real-world primary care settings. Traditional methods of collaboration yielded mixed results, making obvious a need for dedicated collaboration funds and a better framework to identify and align high-yield opportunities.

CONCLUSIONS These projects confirm the feasibility of health behavior counseling in primary care practice. They also highlight the need for substantive practice redesign, and the value of models and frameworks to guide redesign and collaborative efforts.

Ann Fam Med 2005;3(Suppl 2):S4-S12. DOI: 10.1370/afm. 378.

\section{INTRODUCTION}

$\mathrm{T}$ The most common causes of disease, disability, premature death, and health care burden in the United States can be directly attributed to 4 health risk behaviors: smoking tobacco, risky use of alcohol, unhealthy diet, and physical inactivity. ${ }^{1,2}$ An estimated $77 \%$ of adults are inactive, $58 \%$ are overweight, $23 \%$ smoke, and $11 \%$ engage in risky drinking. ${ }^{3}$ Consistent evidence indicates that these behavioral risk factors present in clusters in individuals and populations, ${ }^{4-7}$ and although considerable progress has been made to address these behaviors one at a time ${ }^{8-12}$ large gaps remain in the delivery of proven single-behavior interventions ${ }^{8-14}$ and in the development of effective strategies for addressing these multiple behaviors simultaneously. ${ }^{15}$ Parallel to these urgent problems is a failing health care system that falls short of providing the type of health care that people need, want, and deserve. ${ }^{16}$

In the United States more people see primary care clinicians than any other part of the health care system. ${ }^{17}$ These clinicians confront practice conditions wherein patients' immediate needs demand attention, and they often lack the time, skills, resources, practical tools, and reimbursement systems to counsel patients toward sustainable health behavior change. ${ }^{18,19}$

The call to redesign health care overall and primary care in particular 
stresses patient-centered, integrated care across clinical practice, the community, and the health care system. ${ }^{16}$ A new model of primary care practice requires comprehensive redesign to meet a full range of patient needs, including health behavior counseling. This new model of practice requires multidisciplinary care teams, shared decision making, access to services beyond clinic walls, and electronic information systems designed to support clinicians and patients. ${ }^{20-23}$

A series of studies conducted by the Center for the Advancement of Health found that even in the absence of an integrated health care system, great opportunity to influence personal health choices exists untapped in the nation's primary care offices. ${ }^{19}$ Millions of people identify these primary care clinicians as their usual source of care, ${ }^{24}$ value their advice, and are motivated to act on that advice. ${ }^{17,19}$

Recognizing that primary care practices could have considerable impact on health-related behaviors, the Robert Wood Johnson Foundation (RWJF) ${ }^{25}$ organized a national invitational meeting of practice-based research network (PBRN) leaders, practicing clinicians, practice staff members, and community partners, along with leading researchers in health behavior change, chronic illness care, and practice change. This conference engaged the perspectives of the potential participants to inform the design of a new research initiative and identified the potential of community-practice partnerships ${ }^{18}$ and the need to reconcile idealized models of health promotion and the realities of most practices.

Prescription for Health: Promoting Healthy Behaviors in Primary Care Research Networks ${ }^{26}$ is a national RWJF initiative that unites these developments into a $\$ 9$ million, 5-year program. The program aims to identify, test, and evaluate practical, evidence-based tools, cues, and techniques to improve the delivery and effectiveness of health behavior change strategies in routine primary care practice. It focuses on 4 leading health risk behaviors associated with premature death: smoking tobacco, risky drinking, unhealthy diet, and physical inactivity. In its first phase of funding (Round 1), Prescription for Health funded 17 exploratory projects that tested the feasibility of incorporating innovative behavior change strategies in primary care practices. In this article, we report findings from Round 1, which began in July 2003 and concluded in October 2004.

The goal of Round 1 was to explore whether and how a variety of innovative approaches could feasibly be installed into the existing organizational structure of primary care practices. Seventeen family medicine, internal medicine, pediatric, and nursing PBRNs from across the nation (Figure 1 ) were funded to carry out exploratory projects for at least 2 of the 4 target behaviors. Projects focused on the feasibility of tools, cues, and techniques for improving the delivery and reach of health behavior counseling in routine primary care practice. Rather than prescribe specific types of projects, the program invited PBRNs to imagine what innovations were achievable in current practice conditions. The 17 PBRNs received modest grants of $\$ 125,000$ each and worked within an aggressive 16-month time frame to implement their projects. The networks were not required to report patient outcomes in this first round. Instead, RWJF funded an independent analysis team (A-Team) to analyze project proposals, field notes of site visits, program meeting notes, project interviews, and network entries posted to online diaries to identify characteristics that support successful implementation and adherence to behavior change interventions in the primary care setting. ${ }^{27}$

Instead of addressing 1 behavior at a time, strategies funded by Prescription for Health addressed multiple behaviors. ${ }^{15}$ Six of the 17 projects addressed all 4 target behaviors, 1 project addressed 3 behaviors, and 10 projects addressed 2 behaviors (Table 1 ). Projects were implemented in a total of 120 family medicine, internal medicine, pediatric, and nursing practices across an ethnically diverse sample of adults, adolescents, and children in rural and urban settings. These practices included solo and group practices, Federally Qualified Health Centers, and community nursing centers. Table 1 summarizes the projects as proposed.

\section{METHODS}

The National Program Office, which serves as the program's headquarters, reviewed 3 data sources. Reports from 8 site visits, each lasting 2 days, to selected PBRNs included an assessment of their political support, analytical approach, operations, and research capacity, and an analysis of their strengths, weaknesses, opportunities, and threats. Midpoint (8-month) progress reports included accomplishments to date, preliminary results, major challenges encountered, and possible opportunities for further research. Semifinal (15-month) progress reports included a description of the final project, which in many instances was modified from what was initially proposed, preliminary findings, and overarching lessons. Notes from 3 face-to-face national meetings with the 17 PBRNs included common experiences reported by representatives from the PBRN research teams about project implementation challenges and strategies to address them, issues related to different models and frameworks guiding the design of their projects, potential synergies among projects, and ideas to foster their collaboration.

Iterative discussions of these 3 data sets with the A-Team, consultants, national advisory board members, 


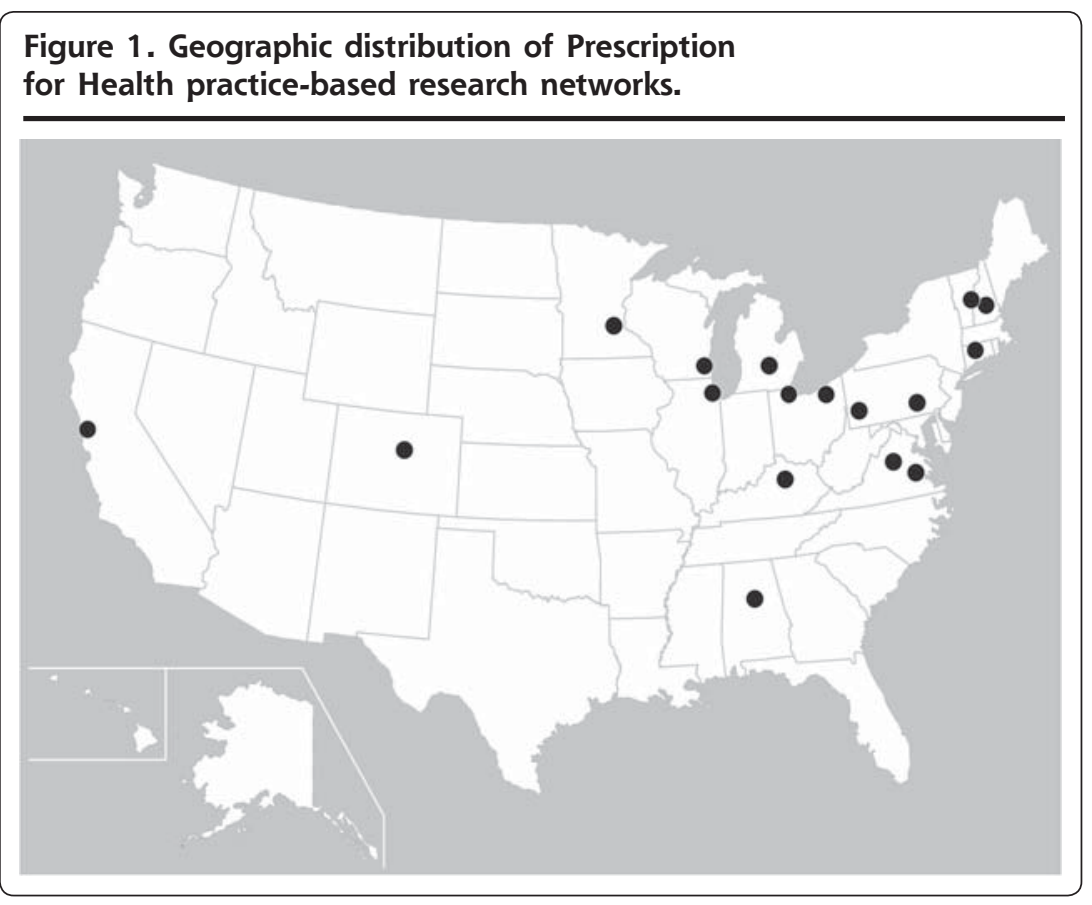

and RWJF staff were used to generate 4 overarching, initiative-wide lessons from Round 1.

\section{RESULTS}

\section{Lessons Learned}

We learned 4 lessons from our analyses of data from Round 1 of Prescription for Health.

\section{Lesson 1: Health Behavior Counseling Can Be Done} in Frontline Primary Care Practice

Clinicians, practice staff, and patients were receptive to the tools, cues, and techniques that were tested in Prescription for Health. The single greatest challenge reported by the PBRNs was the logistics of project implementation in practices with different cultural, geographic, staffing, and ownership configurations. PBRNs developed a myriad of innovative solutions to address these challenges including (1) revising patient recruitment strategies to address seasonal concerns, such as summer physical examinations and influenza; (2) developing effective reminder systems, such as medical record flags, prescription pads, posters, and electronic reminders to continuously prompt practices to use available resources; (3) using teleconferencing and videoconferencing to provide regular reinforcement, training, and assistance to practices spread throughout the PBRNs; (4) identifying techniques to cope with altered work flow, such as strategic use of front desk personnel, medical assistants, and nurses to conduct health risk assessment and, in some instances, part or all of the patient counseling $_{i}$ (5) restructuring the configuration of check-in counters and waiting areas to accommodate the innovations being tested; and (6) forming partnerships with community groups by engaging opinion leaders, attending community meetings, and actively seeking opportunities to create linkages with community resources, such as local walking clubs, fitness centers, support groups, and other community agencies, to optimize available resources to patients outside the office.

Despite logistical barriers, all 17 networks succeeded in implementing the proposed strategies in different locations in the practice and in the community (summarized in Table 1), verifying that it is challenging but possible to install these types of strategies in busy primary care practices to improve health behavior counseling.

Lesson 2: Increased Health Behavior Counseling in Primary Care Requires Substantive Practice Redesign As networks tested their practice innovations, they identified practice constraints that complicated implementation. Such constraints included (1) the lack of established communication systems for staff members, such as regular practice meetings $;$ (2) multiple ways to use and maintain medical records, ranging from $100 \%$ paper to a combination of paper and electronic to full electronic medical records; (3) different ways to identify, track, and follow up with patients who have risk behaviors, such as random notations in medical records, patient registries for specific diseases, and paper and electronic reminders at well-patient visits; (4) diverse roles that practice staff play in patient behavior change, ranging from completely physician-centered to nurse- and physician-centered to involving the entire practice staff ${ }_{i}(5)$ different uses of patient resources, ranging from paper handouts to community resource Web sites to formal referral to dietitians, fitness experts, and telephone or group counseling; and (6) ineffective reimbursement and incentive systems to cover the cost of behavior counseling.

In spite of these obstacles, Round 1 experience showed that distributing the effort across a care team and beyond the examination room is possible. Care to patients who are modifying their behavior can be delivered in and outside of the examination room (eg, at reception desks or weigh-in stations, in conference 


\section{Table 1. Characteristics of Prescription for Health Projects}

\begin{tabular}{|c|c|c|c|c|c|}
\hline PBRN & $\begin{array}{l}\text { Behaviors } \\
\text { Addressed }\end{array}$ & $\begin{array}{l}\text { Target } \\
\text { Population }\end{array}$ & $\begin{array}{l}\text { Activation } \\
\text { Point }\end{array}$ & Tools & Techniques \\
\hline $\begin{array}{l}\text { Alabama Practice Based } \\
\text { Research Network } \\
\text { (APBRN) }\end{array}$ & $\begin{array}{l}\text { Diet, } \\
\text { tobacco }\end{array}$ & Adult & Clinician & PDA, health advisor/coach & $\begin{array}{l}5 \text { A's, motivational interview- } \\
\text { ing, goal setting/action plan, } \\
\text { community links, e-mail } \\
\text { follow-up }\end{array}$ \\
\hline $\begin{array}{l}\text { Clinicians Enhancing } \\
\text { Child Health (CECH) }\end{array}$ & $\begin{array}{l}\text { Activity, diet, } \\
\text { tobacco, } \\
\text { drinking }\end{array}$ & $\begin{array}{l}\text { Adolescent } \\
\text { (12-18 } \\
\text { years) }\end{array}$ & $\begin{array}{r}\text { Clinician, } \\
\text { patient }\end{array}$ & $\begin{array}{l}\text { PDA, health advisor/coach, } \\
\text { educational materials, } \\
\text { patient assessment/screen }\end{array}$ & $\begin{array}{l}5 \text { A's, motivational interview- } \\
\text { ing, goal setting/action plan, } \\
\text { community links, e-mail fol- } \\
\text { low-up, clinician training }\end{array}$ \\
\hline $\begin{array}{l}\text { Colorado Research } \\
\text { Network (CaReNet), } \\
\text { High Plains Research } \\
\text { Network (HPRN) }\end{array}$ & Activity, diet & Adult & $\begin{array}{l}\text { Clinician, staff, } \\
\text { patient }\end{array}$ & $\begin{array}{l}\text { Pedometer, patient assess- } \\
\text { ment/screen, activity/nutri- } \\
\text { tion logs, prescription pad }\end{array}$ & $\begin{array}{l}\text { Clinician/staff modeling of } \\
\text { behavior change, goal set- } \\
\text { ting/action plan, telephone } \\
\text { follow-up }\end{array}$ \\
\hline $\begin{array}{l}\text { Dartmouth-Northern } \\
\text { New England COOP } \\
\text { Project }\end{array}$ & $\begin{array}{l}\text { Activity, diet, } \\
\text { tobacco, } \\
\text { drinking }\end{array}$ & Adult & $\begin{array}{l}\text { Patient, prac- } \\
\text { tice, health } \\
\text { plan, } \\
\text { community }\end{array}$ & $\begin{array}{l}\text { Web site, registry, patient } \\
\text { assessment/screen, vital signs }\end{array}$ & $\begin{array}{l}5 \text { A's, goal setting/action plan, } \\
\text { community links, group } \\
\text { visits, telephone follow-up, } \\
\text { e-mail follow-up, motiva- } \\
\text { tional interviewing }\end{array}$ \\
\hline $\begin{array}{l}\text { Great Lakes Research } \\
\text { Into Practice Network } \\
\text { (GRIN) }\end{array}$ & $\begin{array}{l}\text { Activity, diet, } \\
\text { tobacco, } \\
\text { drinking }\end{array}$ & Adult & $\begin{array}{l}\text { Practice, nurse- } \\
\text { consultant }\end{array}$ & Practice assessment, consultant & $\begin{array}{l}5 \text { A's, practice consultation, } \\
\text { goal setting/action plan }\end{array}$ \\
\hline $\begin{array}{l}\text { Kentucky Ambulatory } \\
\text { Network (KAN) }\end{array}$ & $\begin{array}{l}\text { Activity, } \\
\text { tobacco }\end{array}$ & Adult & Patient & $\begin{array}{l}\text { Prescription pad, health advi- } \\
\text { sor/coach, activity/nutrition } \\
\text { logs, educational materials, } \\
\text { patient assessment/screen }\end{array}$ & $\begin{array}{l}\text { Community program, } \\
\text { goal setting/action plan, } \\
\text { telephone follow-up }\end{array}$ \\
\hline $\begin{array}{l}\text { Midwest Nursing Centers } \\
\text { Consortium Research } \\
\text { Network (MNCCRN) }\end{array}$ & Activity, diet & Adult & $\begin{array}{r}\text { Clinician, } \\
\text { patient }\end{array}$ & $\begin{array}{l}\text { Pedometer, nutrition/activity } \\
\text { logs, health advisor/coach, } \\
\text { patient assessment/screen }\end{array}$ & $\begin{array}{l}\text { Group visits, goal setting/action } \\
\text { plan, community links, tele- } \\
\text { phone follow-up }\end{array}$ \\
\hline $\begin{array}{l}\text { Minnesota Academy } \\
\text { of Family Physicians } \\
\text { Research Network } \\
\text { (MAFPRN) }\end{array}$ & $\begin{array}{l}\text { Activity, diet, } \\
\text { tobacco, } \\
\text { drinking }\end{array}$ & Adult & Patient, staff & $\begin{array}{l}\text { Web site, health advisor/ } \\
\text { coach, educational materi- } \\
\text { als, vital signs, patient } \\
\text { assessment/screen }\end{array}$ & $\begin{array}{l}\text { Motivational interviewing, } \\
\text { community links, telephone } \\
\text { follow-up, e-mail follow-up, } \\
\text { clinician training, external } \\
\text { personnel }\end{array}$ \\
\hline $\begin{array}{l}\text { New England Clinicians } \\
\text { Forum (NECF) }\end{array}$ & $\begin{array}{l}\text { Tobacco, } \\
\text { drinking }\end{array}$ & Adult & $\begin{array}{l}\text { Clinician, } \\
\text { staff }\end{array}$ & $\begin{array}{l}\text { Health advisor/coach, educa- } \\
\text { tional materials, vital signs, } \\
\text { patient assessment/screen }\end{array}$ & $\begin{array}{l}\text { Brief intervention, scheduled } \\
\text { follow-up visit, clinician } \\
\text { training }\end{array}$ \\
\hline $\begin{array}{l}\text { Northwest Ohio Primary } \\
\text { Care Research Network } \\
\text { (NOPCRN) }\end{array}$ & Activity, diet & Adult & $\begin{array}{r}\text { Clinician, } \\
\text { patient }\end{array}$ & $\begin{array}{l}\text { PDA, pedometer, activ- } \\
\text { ity/nutrition logs, patient } \\
\text { assessment/screen }\end{array}$ & $\begin{array}{l}\text { Goal setting/action plan, tele- } \\
\text { phone follow-up, clinician } \\
\text { training }\end{array}$ \\
\hline Pediatric PitNet & Activity, diet & $\begin{array}{l}\text { Children } \\
\text { (8-12 years) }\end{array}$ & $\begin{array}{l}\text { Clinician, staff, } \\
\text { parent }\end{array}$ & $\begin{array}{l}\text { BMI chart, health advisor/ } \\
\text { coach, vital signs, edu- } \\
\text { cational materials, activ- } \\
\text { ity/nutrition logs, patient } \\
\text { assessment/screen }\end{array}$ & $\begin{array}{l}\text { Motivational interviewing, } \\
\text { community links, goal set- } \\
\text { ting/action plan, group visits, } \\
\text { clinician training }\end{array}$ \\
\hline $\begin{array}{l}\text { Pediatric Practice } \\
\text { Research Group (PPRG) }\end{array}$ & Activity, diet & $\begin{array}{l}\text { Children } \\
\text { (2-10 years) }\end{array}$ & $\begin{array}{l}\text { Practice, } \\
\text { patient, } \\
\text { parent }\end{array}$ & $\begin{array}{l}\text { PDA, wall chart, educational } \\
\text { materials, vital signs, patient } \\
\text { assessment/screen, practice } \\
\text { assessment }\end{array}$ & $\begin{array}{l}\text { Practice consultation, clinician } \\
\text { training }\end{array}$ \\
\hline $\begin{array}{l}\text { Penn State Ambula- } \\
\text { tory Research Network } \\
\text { (PSARN) }\end{array}$ & Activity, diet & Adult & Staff, patient & $\begin{array}{c}\text { Health advisor/coach, regis- } \\
\text { try, educational materials, } \\
\text { patient assessment/screen }\end{array}$ & $\begin{array}{l}\text { Motivational interviewing, } \\
\text { goal setting/action plan, } \\
\text { community links, telephone } \\
\text { follow-up, e-mail follow-up, } \\
\text { external personnel }\end{array}$ \\
\hline $\begin{array}{l}\text { Research Association of } \\
\text { Practices (RAP) }\end{array}$ & $\begin{array}{l}\text { Activity, diet, } \\
\text { tobacco, } \\
\text { drinking }\end{array}$ & Adult & $\begin{array}{l}\text { Clinician, staff, } \\
\text { patient }\end{array}$ & $\begin{array}{l}\text { Web site, prescription pad, } \\
\text { educational materials, } \\
\text { patient assessment/screen, } \\
\text { practice assessment }\end{array}$ & $\begin{array}{l}\text { Motivational interviewing, } \\
\text { community links }\end{array}$ \\
\hline $\begin{array}{l}\text { Virginia Ambulatory Care } \\
\text { Outcomes Research } \\
\text { Network (ACORN) }\end{array}$ & $\begin{array}{l}\text { Activity, diet, } \\
\text { tobacco, } \\
\text { drinking }\end{array}$ & Adult & $\begin{array}{r}\text { Clinician, } \\
\text { patient }\end{array}$ & $\begin{array}{l}\text { Web site, patient assessment/ } \\
\text { screen, educational materials }\end{array}$ & Community links \\
\hline $\begin{array}{l}\text { Virginia Practice Support } \\
\text { and Research Network } \\
\text { (VaPSRN) }\end{array}$ & $\begin{array}{l}\text { Diet, } \\
\text { tobacco }\end{array}$ & $\begin{array}{l}\text { Adult and } \\
\text { adolescent }\end{array}$ & Clinician & $\begin{array}{l}\text { PDA, vital signs, patient } \\
\text { assessment/screen, practice } \\
\text { assessment }\end{array}$ & Motivational interviewing \\
\hline $\begin{array}{l}\text { UCSF/Stanford Collabora- } \\
\text { tive Research Network } \\
\text { (CRN) }\end{array}$ & $\begin{array}{l}\text { Activity, diet, } \\
\text { tobacco }\end{array}$ & Adult & Clinician & Patient assessment/screen & $\begin{array}{l}\text { Goal setting/action plan, } \\
\text { clinician training, external } \\
\text { personnel }\end{array}$ \\
\hline
\end{tabular}


rooms), at home and at work (telephone counseling, Web-based information), and in the communities where people live (gyms, parks, walking clubs) as illustrated in Figure 2. Integrating innovations, such as personal digital assistant (PDA) screening tools linked with community behavioral counseling resources, or readiness-to-change assessments linked with a health coach, cannot occur without redesigned work flow, roles, and systems, however.

The importance of integrated systems of care for behavior change is further elaborated on by Woolf et $\mathrm{al}^{28}$ in this supplement. A separate staff and system are not required for every disease and every risk behavior. The adaptive approaches taken in Prescription for Health show promise for addressing multiple risk behaviors in persons with various diseases, possibly creating efficiencies that could enhance the affordability of health behavior counseling in primary care.

Lesson 3: Refinement of Existing Models and Frameworks Based on Frontline Experience Can Guide the Incorporation of Behavior Counseling Into Primary Care Practice

Three specific models were particularly helpful guides for the comprehensive redesign of practice to incorporate health behavior counseling: the Chronic Care
Model, ${ }^{29,30}$ Rogers' model of the diffusion of innovations, ${ }^{31}$ and the 5 A's model. ${ }^{13}$

In designing interventions around multiple risk behaviors, the PBRNs considered factors beyond a single behavior or intervention point (Figure 2). They were not required to organize their work around any particular model, but the Chronic Care Model (CCM) was suggested in the call for proposals as a viable framework. ${ }^{29}$ All the tools, cues, and techniques proposed by the PBRNs mapped to the 6 domains of the CCM as shown in Table 2. Although many of the PBRNs had portions of projects that mapped to pieces of the CCM, most did not explicitly propose a more comprehensive approach to redesigning care. The CCM could be a useful framework for considering more comprehensively how new tools, cues, and techniques for health behavior counseling fit across all the dimensions of care. This model also suggests that the dimensions of comprehensive health behavior counseling substantially overlap and align with current thinking about how practices should approach caring for people with chronic diseases. ${ }^{30}$ It is therefore plausible that primary care practices could redesign their work to address both chronic care and health behavior counseling, resulting in improvements for both.

A second model, Rogers' model of the diffusion of

\section{Figure 2. Integration of health behavior change strategies in primary care.}

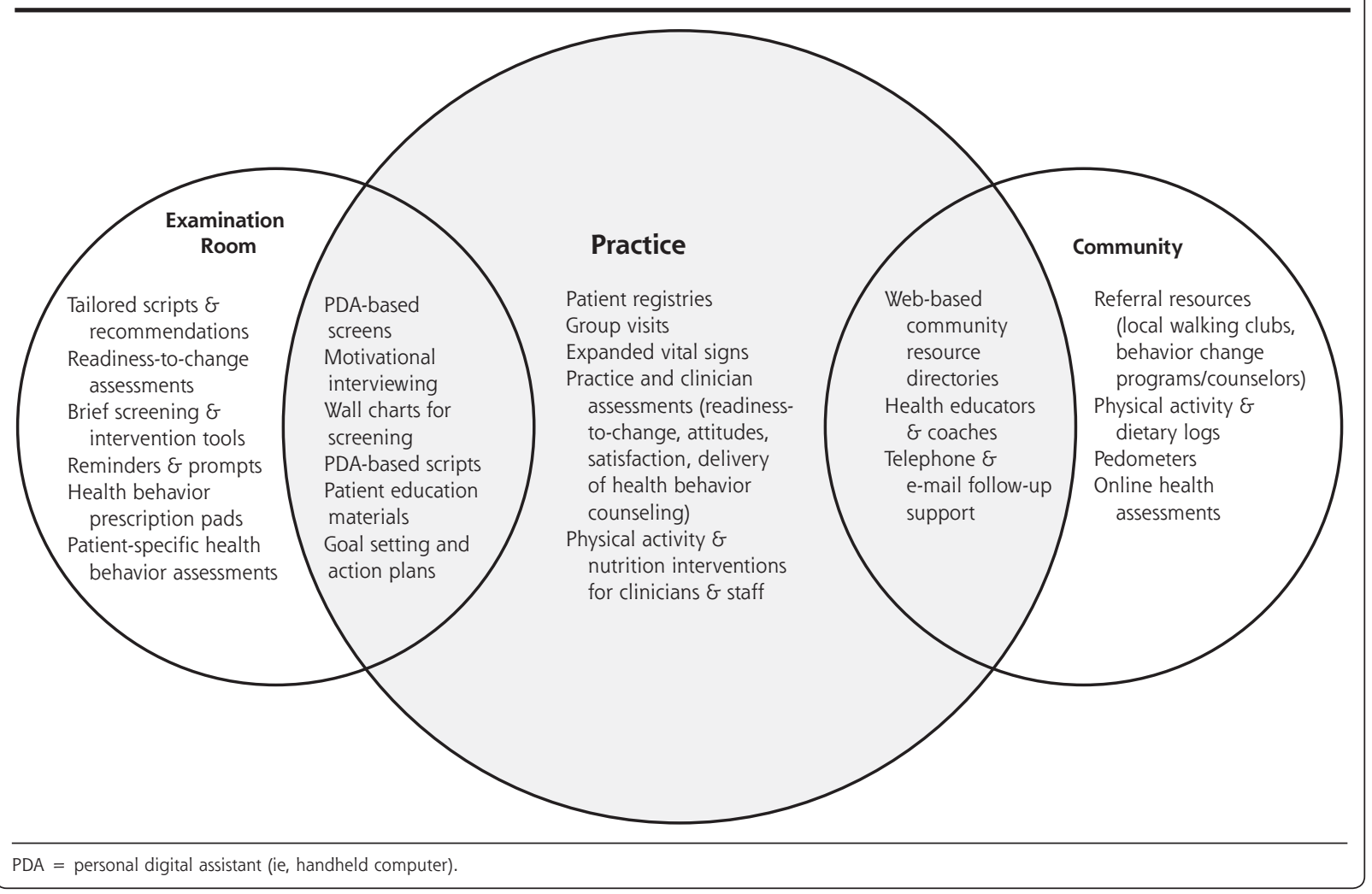


innovations, ${ }^{31}$ acknowledges that innovation is difficult and a good idea alone is not enough. Innovation requires tailoring, revision, and adaptability, along with perseverance and leadership to surmount resistance and foster commitment to new ways of thinking. Most PBRNs found it was necessary to tailor and adapt their interventions midstream to accommodate unanticipated practice needs. These modifications manifested as extended timelines (eg, 15 of 17 PBRNs requested extensions to complete their projects), additional training for practice staff on use of new technology or counseling techniques (eg, PDAs, motivational interviewing, group visits), and changes to data collection strategies (eg, synching data from PDA to a central server). PBRNs recruited physicians, nurses, and other practice staff as practice champions to provide leadership and foster implementation and evaluation for these pilot studies.

The PBRNs recognized that health behavior counseling extends beyond a single patient visit. A third model, the 5 A's model, identifies 5 components (ask, advise, agree, assist, and arrange) that can be sequenced to help patients address unhealthy behaviors. ${ }^{13}$ Several PBRNs used this model to focus their strategies, define boundaries, and create links inside and outside the practice. One project conducted the ask and agree functions in the practice and used a statewide smoking quit line that was prescribed in the examination room to fulfill the advise function and guide patients toward assistance. Another project used a health coach who was linked to the practice to guide patients through the entire counseling sequence, while yet another project conducted the ask function as an additional vital sign, performed the advise, agree, and assist functions through the use of an action plan, and incorporated arrange into a follow-up visit.

These emerging insights point not only to the usefulness of these models and frameworks, but also to the need to adapt and modify them based on the local experiences of those using them within the complexities of real-world settings.

Lesson 4: Coevolution, Rather Than Traditional Collaboration, Can Be a Useful Framework for Creating Synergies Across Projects

In Round 1, the National Program Office used traditional collaboration methods such as e-mail listservs, Web sites, online discussion groups, and face-to-face
Table 2. Strategies Implemented by Prescription for Health Projects by Domain of the Chronic Care Model

\begin{tabular}{|c|c|}
\hline Domain & Implementation Strategies \\
\hline $\begin{array}{c}\text { Community } \\
\text { resources }\end{array}$ & $\begin{array}{l}\text { Locally based community health advisors } \\
\text { Web-based directories of community resources } \\
\text { Web links to relevant information or resources outside } \\
\text { community (regional or national) }\end{array}$ \\
\hline $\begin{array}{l}\text { Health care } \\
\text { organization }\end{array}$ & $\begin{array}{l}\text { Practicewide assessments } \\
\text { Clinician assessments (attitudes, satisfaction, readiness to } \\
\text { change) } \\
\text { Evaluation of use of specific tools or techniques } \\
\text { Negotiated support from insurers for project activities }\end{array}$ \\
\hline $\begin{array}{l}\text { Self-management } \\
\text { support }\end{array}$ & $\begin{array}{l}\text { Patient-centered goal setting and action plans } \\
\text { Motivational interviewing techniques } \\
\text { Physical activity and dietary logs } \\
\text { Community resource directories } \\
\text { Local walking club } \\
\text { Periodic follow-up from health change facilitators, educators, } \\
\text { or advisors } \\
\text { Telephone and e-mail follow-up and support } \\
\text { Pedometers } \\
\text { Tailored behavior change educational materials or information }\end{array}$ \\
\hline $\begin{array}{l}\text { Delivery system } \\
\text { design }\end{array}$ & $\begin{array}{l}\text { Patient questionnaires before visit and ongoing (Web-based) } \\
\text { Staff role changes and education } \\
\text { Health advisors, educators, coaches/health change facilitators } \\
\text { Brief interventions } \\
\text { Periodic health assessments (vital signs and others) } \\
\text { Prescription pads for health behaviors } \\
\text { Group visits } \\
\text { Telephone and e-mail follow-up support }\end{array}$ \\
\hline Decision support & $\begin{array}{l}\text { Patient-reported health behavior information (before, } \\
\text { during, and between visits) } \\
\text { Relevant preventive services guidelines } \\
\text { Patient readiness-to-change assessments } \\
\text { Streamlined evidence-based assessment and screening tools } \\
\text { Tailored scripts and techniques } \\
\text { Patient-tailored care recommendations } \\
\text { Targeted evidence-based recommendations } \\
\text { Electronic (Web, PDA) decision-support tools }\end{array}$ \\
\hline $\begin{array}{l}\text { Clinical } \\
\text { information } \\
\text { systems }\end{array}$ & $\begin{array}{l}\text { Patient registries } \\
\text { Reminder systems (electronic, posters, assessments, patient- } \\
\text { reported behavior indicators, other) } \\
\text { Patient-completed screening tools } \\
\text { Logs and behavioral questionnaires } \\
\text { Expanded vital signs to include risky health behaviors }\end{array}$ \\
\hline
\end{tabular}

meetings, with mixed results. The challenges with this approach included the long distances between PBRNs, the independent nature of grantees, the numerous competing demands faced by the research teams, and the lack of time, incentives, and financial resources to fund the additional costs of collaboration. It became clear that a dedicated pool of money and a better framework were necessary to foster high-yield collaborative opportunities and better align the incentives to the overall 
goals of individual projects and the program. Coevolution provides such a framework.

Coevolution is a biological concept that describes "successive changes among two or more ecologically interdependent but unique species such that their evolutionary trajectories become intertwined over time." ${ }^{132}$ Coevolving, as a relational concept, comes from the business literature and asserts that collaboration should not be forced, but rather allowed to flourish naturally and voluntarily. Coevolution therefore sets the conditions for collaboration but allows synergy and competition to emerge from the ground up, rewarding individual accomplishments, not collaboration. This approach allows teams to choose collaborative strategies that are mutually beneficial based on enlightened self-interest and to choose only those that have the potential for highest yield. This framework recognizes that collaboration is time consuming, resource intensive, high risk, and not always productive. Instead of working toward creating as many synergies and webs of relationships as possible, coevolution takes a strategic approach to building the number and types of collaborative links and continually shifting this web of relationships to capture new opportunities and end nonproductive ones. The goal of coevolving teams is to stay agile and flexible to respond to the changing demands of their work and each other. ${ }^{32}$

\section{Limitations}

The limitations of Round 1 included the short time frame along with the modest amount of funding to support these projects. Several PBRNs obtained supplemental funds from their home institutions or other organizational partners to support additional project costs. Although these drawbacks limited more comprehensive work, the program succeeded in testing the projects' feasibility in current practice conditions, which was the goal of Round 1. The extra burden of innovating and balancing competing demands often resulted in implementation delays, study design changes, practice attrition, and requests for grant extensions. Many projects did not apply a formal organizational change model to guide the incorporation of innovations into practice, which likely contributed to some of the challenges the PBRNs experienced. Unavoidable and desirable variation and tailoring of innovations occurred to facilitate their installment in practices with unique organizational and cultural structures. Diary data that substantiate these limitations are presented by Cohen et $\mathrm{al}^{27}$ in this supplement. Lastly, few projects measured patient outcomes, largely because of insufficient funding and the short time frame of Round 1 . The second round of Prescription for Health focuses on patient outcomes and more standardized measurements across projects.

\section{CONCLUSIONS}

The redesign of health care that is under way presents primary care with compelling opportunities to help patients choose and sustain healthier behaviors. The first round of experience in Prescription for Health confirms keen interest among the nation's frontline primary care clinicians, and the willingness and ability to innovate strategies that can be achieved in frontline practice and that align well with recommendations for new model practice. ${ }^{20-23}$ Progress to date reveals an alignment of approaches useful for addressing health behaviors from a preventive care perspective with that of caring for people with chronic illness. This alignment suggests that in new models of primary care practice, systems created to address primary prevention and chronic care may overlap and create synergies and efficiencies to enable improved prevention and chronic care, possibly avoiding duplication and waste.

Incorporating strategies in primary care practices to change risky behaviors and sustain healthy ones is not easy. Although all the Prescription for Health practices were willing to test the feasibility of incorporating changes into their existing systems, not all were prepared or able to incorporate these changes into their practices as formalized quality improvement measures beyond study completion. This tension is further explained by Bodenheimer et $\mathrm{al}^{33}$ and further substantiated with diary data by Cohen et $\mathrm{al}^{27}$ in this supplement. What is needed next includes the adoption of a quality improvement mind-set by all primary care practices and system reform to sustain these improvements. This need necessarily challenges the status quo, continually looking for better ways to observe, measure, and test small and large changes, even if only informally, and it espouses the belief that all primary care practices can do something now to help their patients be healthier. Such a mind-set must attend to the other important and integrated functions of primary care while working on promoting healthy behaviors. ${ }^{34}$ Another key step is to conduct further assessment of the impact of multifaceted behavior change strategies on practices and patients that aim to integrate what takes place in the examination room, the practice, and the community where patients actually live out their choices.

Round 1 of Prescription for Health confirms that changing a complex system such as a primary care practice is challenging, and pleads for better understanding of how practice can be changed most effectively to help patients adopt healthier behaviors while understanding important aspects of current practice that need to be maintained. With further research and development in the real-world laboratories of PBRNs, and with policy changes particularly to the financing of primary care, improvements in the delivery of care may 
be achieved that affect not a few, but millions of people, reducing avoidable suffering and premature death.

To read or post commentaries in response to this article, see it online at http://www.annfammed.org/cgi/content/full/3/Suppl_2/S4.

Key words: Health behavior change; counseling; health behavior; practice change; primary care redesign; practice-based research network; behavioral/psychosocial; health promotion/disease prevention

Submitted January 19, 2005; submitted, revised, April 19, 2005; accepted April 20, 2005.

Funding support: This work was supported by Prescription for Health, a national program of The Robert Wood Johnson Foundation with support from the Agency for Healthcare Research and Quality.

\section{References}

1. McGinnis JM, Foege W. Actual causes of death in the United States. JAMA. 1993;270:2207-2212.

2. Mokdad AH, Marks JS, Stroup DF, Gerberding JL. Actual causes of death in the United States, 2000. JAMA. 2004;291:1238-1245.

3. Fine LJ, Philogene GS, Gramling R, Coups EJ, Sinha S. Prevalence of multiple chronic disease risk factors: 2001 National Health Interview Survey. Am J Prev Med. 2004;27(Suppl 2):18-24

4. Emmons KM, Shadel WG, Linnan L, Marcus BH, Abrams DB. A prospective analysis of change in multiple risk factors for cancer. Cancer Res Ther Control. 1999;8:15-23.

5. Nigg CR, Allegrante JP, Ory MG. Theory-comparison and multiplebehavior research: common themes advancing health behavior research. Health Educ Res. 2002;17:670-679.

6. Orleans CT, Gruman J, Ulmer C, Emont SL, Hollendonner JK. Rating our progress in population health promotion: report card on six behaviors. Am J Health Promot. 1999;14:75-83.

7. Solomon S, Kington R. National efforts to promote behavior-change research: views from the Office of Behavioral and Social Science Research. Health Educ Res. 2002;17:495-499.

8. Department of Health and Human Services, Public Health Service. Treating Tobacco Use and Dependence: A Clinical Practice Guide, 2000. Washington, DC: National Institutes of Health; 2000. AHRQ publication 00-0032.

9. US Preventive Services Task Force. Behavioral counseling in primary care to promote physical activity: recommendations and rationale. Ann Intern Med. 2002;137:205-207.

10. US Preventive Services Task Force. Behavioral counseling in primary care to promote a healthy diet: recommendations and rationale. Am J Prev Med. 2003;24:93-100.

11. US Preventive Services Task Force. Screening and behavioral counseling interventions in primary care to reduce alcohol misuse: recommendations and rationale. Ann Intern Med. 2004;140:554-557.

12. Centers for Disease Control and Prevention. The guide to community preventive services: tobacco use and prevention. Reviews, recommendations and expert commentary. Am J Prev Med. 2002;20(Suppl 2):1-88.

13. Whitlock EP, Orleans $C T$, Pender N, Allan J. Evaluating primary care behavioral counseling interventions: an evidence-based approach. Am J Prev Med. 2002;22:267-284
14. Coffield AB, Maciosek MV, McGinnis JM, et al. Priorities among recommended clinical preventive services. Am J Prev Med. 2001;21:1-9.

15. Pronk NP, Peek CJ, Goldstein MG. Addressing multiple behavioral risk factors in primary care. A synthesis of current knowledge and stakeholder dialogue sessions. Am J Prev Med. 2004;27(2 Suppl):4-17.

16. Committee on Quality of Health Care in America. Institute of Medicine. Crossing the Quality Chasm: A New Health System for the 21st Century. Washington, DC: National Academies Press; 2001.

17. Green LA, Fryer GE, Yawn BP, Lanier D, Dovey SM. The ecology of medical care revisited. N Engl J Med. 2001;344:2021-2025.

18. Stange KC, Woolf SH, Gjeltema K. One minute for prevention: the power of leveraging to fulfill the promise of health behavior counseling. Am J Prev Med. 2002;22:320-323.

19. Center for the Advancement of Health. Integration of Health Behavior Counseling in Routine Medical Care. Washington, DC: Center for the Advancement of Health; 2001.

20. Future of Family Medicine Project Leadership Committee. The future of family medicine: a collaborative project of the family medicine community. Ann Fam Med. 2004;2(Suppl 1):S3-S32.

21. Sandy LG, Schroeder SA. Primary care in a new era: disillusion and dissolution? Ann Intern Med. 2003;138:262-267.

22. Ludwig S. Academic general pediatrics: from endangered species to advanced scholars of general pediatrics. The report of a consensus conference. Ambul Pediatr. 2004;4:407-410.

23. Showstack J, Rothman AA, Hassmiller SB. The Future of Primary Care. San Francisco, Calif: Jossey-Bass; 2004.

24. Center for Policy Studies in Family Practice and Primary Care. The importance of having a usual source of health care [policy center one-pager]. Am Fam Physician. 2000;62:477.

25. Robert Wood Johnson Foundation. Web site. Available at: http:// www.rwjf.org.

26. Prescription for Health. Web site. Available at: http://www.prescriptionforhealth.org.

27. Cohen DJ, Tallia AF, Crabtree BF, Young DM. Implementing health behavior change in primary care: lessons from Prescription for Health. Ann Fam Med. 2005;3(Suppl 2):S12-S19.

28. Woolf SH, Glasgow RE, Krist A, et al. Putting it together: finding success in behavior change through integration of services. Ann Fam Med. 2005;3(Suppl 2):S20-S27.

29. Wagner EH, Austin BT, Von Korff M. Organizing care for patients with chronic illness. Milbank Q. 1996;74:511-544.

30. Glasgow RE, Orleans CT, Wagner EH, Curry SJ, Solberg LI. Does the Chronic Care Model serve also as a template for improving prevention? Milbank Q. 2001;79:579-612.

31. Rogers EM. Diffusion of Innovations. New York, NY: Free Press; 2003.

32. Eisenhardt KM, Galunic DC. Coevolving: at last, a way to make synergies work. Harv Bus Rev. 2000;Jan/Feb:91-101.

33. Bodenheimer T, Young DM, MacGregor K, Holtrop JS. Practice-based research in primary care: facilitator of or barrier to practice improvement? Ann Fam Med. 2005;3(Suppl 2):S28-S32.

34. Stange KC. The paradox of the parts and the whole in understanding and improving general practice. Int J Qual Health Care. 2002;14:267268. 